Article

\title{
Phytochemical and Biological Traits of Endemic Betonica bulgarica (Lamiaceae)
}

\author{
Tsvetelina Mladenova ${ }^{1}$, Plamen Stoyanov ${ }^{1,2} \mathbb{D}$, Krasimir Todorov ${ }^{1}$, Delyana Davcheva ${ }^{3,4}$, Gergana Kirova ${ }^{4,5}$, \\ Tanya Deneva ${ }^{3,4}$, Donika Gyuzeleva ${ }^{1}$, Rumen Mladenov ${ }^{1,2}$ and Anelia Bivolarska ${ }^{6, *}$ \\ 1 Department of Botany and Methods of Biology Teaching, Faculty of Biology, University of Plovdiv \\ "Paisii Hilendarski", 24 Tzar Assen Street, 4000 Plovdiv, Bulgaria; cmladenova@uni-plovdiv.bg (T.M.); \\ rummlad@uni-plovdiv.bg (R.M.); pstoyanov@uni-plovdiv.bg (P.S.); ktodorov@uni-plovdiv.bg (K.T.); \\ donikag@uni-plovdiv.bg (D.G.) \\ 2 Department of Bioorganic Chemistry, Faculty of Pharmacy, Medical University of Plovdiv, 15A Vasil Aprilov \\ Boulevard, 4000 Plovdiv, Bulgaria \\ 3 Department of Clinical Laboratory, Faculty of Pharmacy, Medical University of Plovdiv, 15A Vasil Aprilov \\ Boulevard, 4000 Plovdiv, Bulgaria; Delyana.Davcheva@mu-plovdiv.bg (D.D.); \\ Tanya.Deneva@mu-plovdiv.bg (T.D.) \\ 4 Division of Pharmaceutical Innovations for Personalized Medicine, Research Institute at Medical University \\ of Plovdiv, 15A Vasil Aprilov Boulevard, 4000 Plovdiv, Bulgaria \\ 5 Department of Chemical Sciences, Faculty of Pharmacy, Medical University of Plovdiv, 15A Vasil Aprilov \\ Boulevard, 4000 Plovdiv, Bulgaria; Gergana.Kirova@mu-plovdiv.bg \\ 6 Department of Medical Biochemistry, Faculty of Pharmacy, Medical University of Plovdiv, 15A Vasil Aprilov \\ Boulevard, 4000 Plovdiv, Bulgaria \\ * Correspondence: anelia.bivolarska@mu-plovdiv.bg; Tel.: +359-887611786
}

Citation: Mladenova, T.; Stoyanov, P.; Todorov, K.; Davcheva, D.; Kirova, G.; Deneva, T.; Gyuzeleva, D.; Mladenov, R.; Bivolarska, A. Phytochemical and Biological Traits of Endemic Betonica bulgarica (Lamiaceae). Separations 2021, 8, 11. https://doi.org/10.3390/ separations 8020011

Received: 7 January 2021

Accepted: 20 January 2021

Published: 23 January 2021

Publisher's Note: MDPI stays neutral with regard to jurisdictional claims in published maps and institutional affiliations.

Copyright: (c) 2021 by the authors. Licensee MDPI, Basel, Switzerland. This article is an open access article distributed under the terms and conditions of the Creative Commons Attribution (CC BY) license (https:/ / creativecommons.org/licenses/by/ $4.0 /)$.

\begin{abstract}
Betonica bulgarica is an endemic species distributed in Bulgaria. The chemical composition of the essential oil analysed by GC-MS (Gas chromatography-mass spectrometry) and the content of trace elements analysed by ICP-MS (Inductively coupled plasma mass spectrometry) were determined. Additionally, a study on the types and distribution of trichomes was done using a microscope with a camera. The essential oil was characterized using a high concentration of sesquiterpene hydrocarbons, whose major compounds are $\beta$-caryophyllene $(17.4 \%)$, germacrene D $(9.9 \%)$, and $\beta$-bourbonene $(6.7 \%)$. The contents of manganese $(177.2 \mu \mathrm{g} / \mathrm{g})$ and strontium $(156.8 \mu \mathrm{g} / \mathrm{g})$ were highest among the investigated micronutrients. Two types of trichomes were identified on the adaxial and abaxial epidermises of the leaves of B. bulgarica-covering and glandular. Peltate stacked glandular trichomes with a four-celled head of type B were observed on the leaf surface.
\end{abstract}

Keywords: Betonica bulgarica; ICP-MS (Inductively coupled plasma mass spectrometry); GC-MS (Gas chromatography-mass spectrometry); multielement analysis; trace elements; trichomes; endemic; essential oil; lamiaceae

\section{Introduction}

Endemic plants make up $12.8 \%$ of the representatives of Bulgarian flora and have specificity and certain genetic peculiarities [1]. They are some of the most sensitive and vulnerable natural ecosystems in the country [2].

The genus Betonica L. is separate from the genus Stachys L., with four species [3]. The taxonomic independence of two of them-Betonica officinalis and Betonica bulgarica-is currently controversial.

In Bulgaria, B. officinalis can be found throughout the country at an altitude of up to $1400 \mathrm{~m}$ in grassy and shrubby areas [4]. B. officinalis is used in folk medicine for the treatment of nervous exhaustion, gallstones, stomach acids, high blood pressure, migraine, and neuralgia, as an ointment for cuts and wounds as well as against sweating $[5,6]$.

The Bulgarian endemic B. bulgarica Degen et Neič. (Stachys bulgarica Hayek), described by the Hungarian botanist A. V. Degen and the Bulgarian botanist I. Neichev in 1906 on 
the basis of materials collected in the Central Stara Planina Mountains, grows outdoors in stony and sandy soils in oak and beech forests of the Stara Planina Mountains (Central, East) and the Thracian Lowlands [7-9]. B. bulgarica is an endemic plant protected by the Biological Diversity Act [10] and included in the Red Data Book of Bulgaria under the category "endangered" [9]. Three flavonoids have been found in significant amounts in B. bulgarica - rutin, quercetin, and hispidulin—associated with the antioxidant activity of the plant [11].

In recent years, the Bulgarian populations of B. bulgarica have been studied by Grozeva et al. [12-14]. Along with morphological, palinomorphological, and ecological studies, the authors also draw attention to the epidermis covering the leaves, stems, and flower parts of the plants as the main structure responsible for the accumulation of essential oils.

Although the healing properties of the species of the Lamiaceae family are likely due to their essential oils and flavonoids, in recent years, there has also been increasing interest in certain trace elements [15], whose presence could have a synergistic effect with these components [16]. Most trace elements are essential for higher plants, mainly in the composition of metalloenzymes and metalloproteins. They are also involved in a number of redox processes, processes of photosynthesis, breathing, expression and regulation of genes, protein synthesis, and protective mechanisms of plants [17]. So far, there have been no data on the presence of trace elements in B. bulgarica species.

The purpose of this study was to complement the available information about the endemic species B. bulgarica with regard to the anatomic morphological structures of the epidermis, the essential oil composition, and the microelement composition of the species from the plant habitat, which we discovered in the Bulgarka Nature Park.

\section{Results and Discussion}

\subsection{Biological Traits}

Analysing the leafy and stem surfaces of B. bulgarica, two types of trichomes were identified: covering trichomes and glandular trichomes. The results obtained are in accordance with the claims of Metcalfe and Chalk [18], Maleci Bini and Giuliani [19], and Mladenova et al. [20] regarding the types of trichomes in the representatives of the Lamiaceae family.

In this study, two types of trichomes were identified on the upper and lower epidermises of the leaves of $B$. bulgarica-covering and glandular. Covering trichomes are multicellular linear unbranched, whereas glandular trichomes are peltate stacked with a four-celled head (Figure 1).

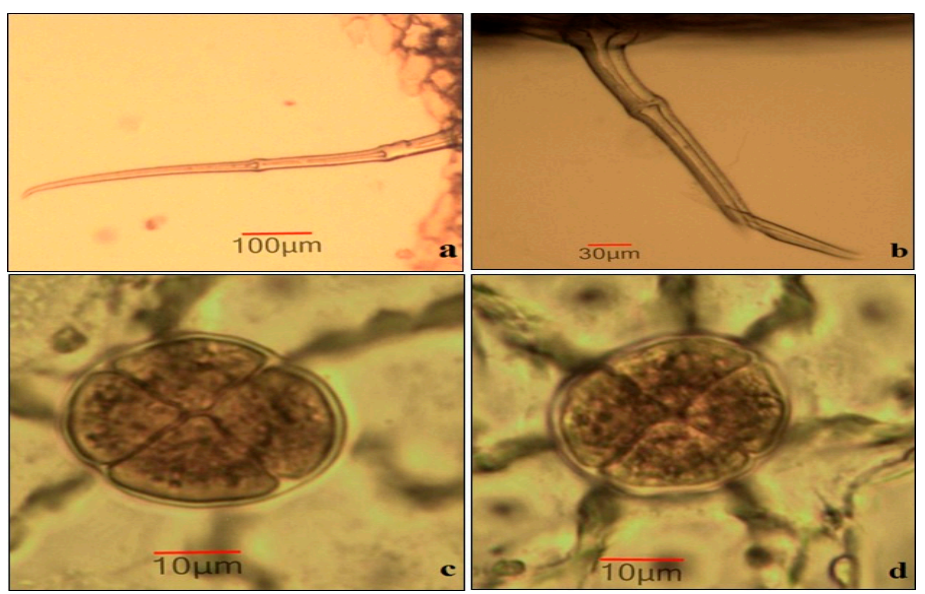

Figure 1. Trichomes on the leaf surface: (a) multicellular linear unbranched covering trichome on the adaxial epidermis; (b)multicellular linear unbranched covering trichome on the abaxial epidermis; (c) peltate stacked glandular trichome with a four-celled head on the adaxial epidermis; (d) peltate stacked glandular trichome with a four-celled head on the abaxial epidermis. 
According to the descriptions of Giuliani and Maleci Bini [21], this type of glandular trichomes belongs to type B, where the secreting cell has a bicellular or quadricellular structure. Giuliani et al. [22] reported that this type of trichomes is mainly characterized by polysaccharide content.

Upon examining the stem surface, apart from multicellular linear unbranched trichomes, the presence of capitate stacked trichomes was also identified, which, however, end with a unicellular head (Figure 2). The presence of such multicellular glandular trichomes with a unicellular head was reported by Ya'ni et al. [23] regarding other species of the Lamiaceae family as well.

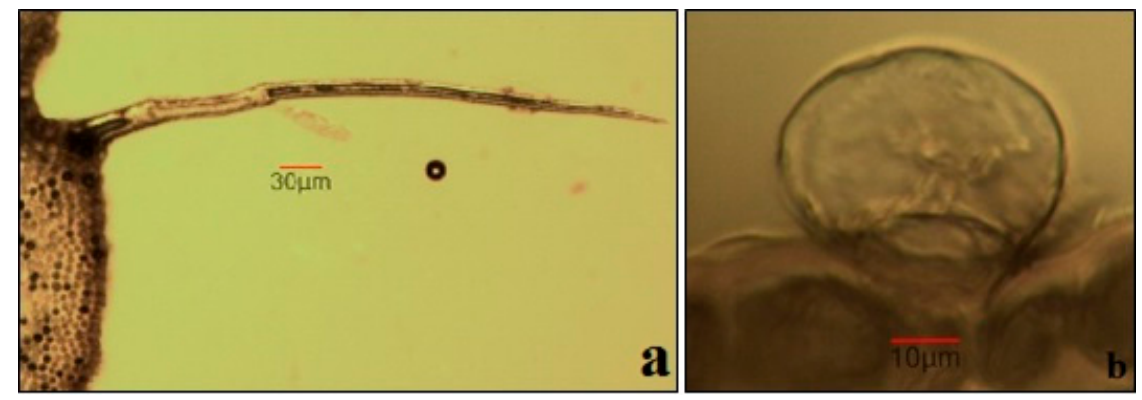

Figure 2. Trichomes on the stem surface: (a) multicellular linear unbranched covering trichome; (b) capitate stacked glandular trichome with a unicellular head.

\subsection{Analysis of Essential Oils (GC-MS)}

The total number of chemical constituents identified in essential oils was 64 for B. bulgarica. The highest yield of essential oil was extracted from the leaves, then from the flower, and then from the stem. The specific identified compounds and their percentages are compiled in Tables 1 and 2. The main constituents of the essential oil were sesquiterpene hydrocarbons ( $\beta$-caryophyllene, $17.4 \%$, and germacrene $\mathrm{D}, 9.9 \%$ ).

Table 1. Essential oil content of the samples being examined.

\begin{tabular}{ccc}
\hline \multirow{2}{*}{ Sample } & \multicolumn{2}{c}{ Quantity of Essential Oil } \\
\cline { 2 - 3 } & $\mathbf{m g}$ & \% w/w (Dry Matter) \\
\hline Betonica bulgarica-leaves & 5.04 & 0.10 \\
Betonica bulgarica-stem & 1.85 & 0.04 \\
Betonica bulgarica-flower & 3.73 & 0.07 \\
\hline
\end{tabular}

Table 2. Phytochemical composition [\%] of essential oils.

\begin{tabular}{cccccc}
\hline No. & KI & Compound & Leaf & Stem & Flower \\
\hline 1 & 855 & trans-Hexenal & 0.6 & $\operatorname{tr}$ & 0.1 \\
2 & 939 & $\alpha$-Pinene & 0.9 & $\operatorname{tr}$ & 2.0 \\
3 & 960 & Benzaldehyde & $\operatorname{tr}$ & $\operatorname{tr}$ & 0.3 \\
4 & 979 & 1-Octen-3-ol & 3.6 & 0.5 & 0.7 \\
5 & 985 & 6-Methyl-5-hepten-2-one & $\operatorname{tr}$ & n.d. & 0.1 \\
6 & 988 & 2-Pentylfuran & $\operatorname{tr}$ & n.d. & 0.1 \\
7 & 990 & Myrcene & 0.1 & n.d. & n.d. \\
8 & 1007 & trans trans-2,4-Heptadienal & 0.2 & n.d. & 0.1 \\
9 & 1031 & Benzyl alcohol & $\operatorname{tr}$ & n.d. & 0.2 \\
10 & 1042 & Benzene acetaldehyde & 0.5 & 0.1 & 1.0 \\
11 & 1081 & 4-Methylbenzaldehyde & 0.1 & n.d. & 0.4 \\
12 & 1096 & Linalool & 1.7 & 1.2 & 0.7 \\
13 & 1100 & Undecane & 0.1 & 0.7 & tr \\
14 & 1108 & Phenyl ethyl alcohol & 0.6 & 0.8 & 0.9 \\
15 & 1126 & $\alpha$-Campholenal & $\operatorname{tr}$ & $\operatorname{tr}$ & 0.2 \\
\hline
\end{tabular}


Table 2. Cont.

\begin{tabular}{|c|c|c|c|c|c|}
\hline No. & KI & Compound & Leaf & Stem & Flower \\
\hline 16 & 1144 & trans-Verbenol & 0.4 & 0.2 & 0.3 \\
\hline 17 & 1188 & $\alpha$-Terpineol & n.d. & 0.4 & 0.1 \\
\hline 18 & 1195 & Myrtenol & n.d. & n.d. & 0.1 \\
\hline 19 & 1167 & Octanoic acid & 1.1 & 1.1 & 0.6 \\
\hline 20 & 1205 & Verbenone & 0.2 & $\operatorname{tr}$ & 0.1 \\
\hline 21 & 1284 & trans-Anethole & 0.2 & 0.7 & 0.4 \\
\hline 22 & 1293 & 2,4-Decadienal & $\operatorname{tr}$ & n.d. & 0.2 \\
\hline 23 & 1351 & $\alpha$-Cubebene & 1.0 & 0.9 & 0.4 \\
\hline 24 & 1359 & Eugenol & 0.6 & 0.7 & 0.3 \\
\hline 25 & 1375 & $\alpha$-Ylangene & 0.5 & 0.4 & 0.3 \\
\hline 26 & 1376 & $\alpha$-Copaene & 1.6 & 1.1 & 1.1 \\
\hline 27 & 1388 & $\beta$-Bourbonene & 6.7 & 5.4 & 2.0 \\
\hline 28 & 1420 & $\beta$-Ylangene & 0.8 & 0.4 & $\operatorname{tr}$ \\
\hline 29 & 1390 & $\beta$-Elemene & 0.2 & 0.5 & 1.6 \\
\hline 30 & 1408 & Iso-caryophyllene & $\operatorname{tr}$ & 0.1 & 0.2 \\
\hline 31 & 1419 & $\beta$-Caryophyllene & 8.6 & 5.9 & 17.4 \\
\hline 32 & 1432 & $\beta$-Copaene & 2.8 & 2.1 & 1.0 \\
\hline 33 & 1434 & trans- $\alpha$-Bergamotene & $\operatorname{tr}$ & $\operatorname{tr}$ & 0.3 \\
\hline & 1433 & Gurjunene + Aromadendrene & 0.3 & 0.3 & 0.4 \\
\hline 34 & 1441 & & & & \\
\hline 35 & 1454 & $\alpha$-Humulene & 3.9 & 2.8 & 6.4 \\
\hline 36 & 1456 & trans- $\beta$-Farnesene & 1.3 & 1.7 & 1.8 \\
\hline 37 & 1479 & $\gamma$-Muurolene & 5.7 & 4.8 & 2.6 \\
\hline 38 & 1481 & Germacrene D & 9.9 & 2.4 & 3.6 \\
\hline 39 & 1488 & trans- $\beta$-Ionone + Unknown & 1.1 & 1.1 & n.d. \\
\hline 40 & 1500 & $\alpha$-Muurolene & 0.5 & 2.4 & $\operatorname{tr}$ \\
\hline 41 & 1512 & Amorphene & 0.3 & 0.3 & 0.3 \\
\hline 42 & 1513 & $\gamma$-Cadinene & 4.8 & 4.3 & 0 \\
\hline 43 & 1523 & $\delta$-Cadinene & 6.0 & 4.6 & 2.9 \\
\hline 44 & 1534 & Cadina-1,4-diene & 0.3 & 0.5 & 0.1 \\
\hline 45 & 1538 & $\alpha$-Cadinene & 0.5 & 0.6 & 0.1 \\
\hline 46 & 1545 & $\alpha$-Calacorene & 0.4 & 0.6 & 0.2 \\
\hline 47 & 1563 & 1-nor-Bourbonanone & 0.2 & 0.6 & 0.1 \\
\hline 48 & 1565 & $\beta$-Calacorene & 0.2 & 0.6 & 0.2 \\
\hline 49 & 1563 & Nerolidol & 0.2 & $\operatorname{tr}$ & 0.2 \\
\hline 50 & 1578 & Spatulenol & 0.8 & 0.5 & 0.3 \\
\hline 51 & 1582 & Caryophyllene oxide & 3.4 & 4.7 & 5.2 \\
\hline 52 & 1584 & $\beta$-Copaen-4- $\alpha$-ol & 1.0 & 1.2 & 0.3 \\
\hline 53 & 1594 & Salvial-4(14)-en-1-one & 0.6 & 0.8 & 0.2 \\
\hline 54 & 1608 & Humulene 1,2-epoxide & 1.3 & 1.9 & 1.5 \\
\hline 55 & 1640 & $\tau$-Cadinol & 1.0 & 1.5 & 0.6 \\
\hline 56 & 1650 & $\beta$-Eudesmol & 0.7 & 2.1 & 1.3 \\
\hline 57 & 1654 & $\alpha$-Cadinol & 1.1 & 1.8 & 1.3 \\
\hline 58 & 1913 & Farnesyl acetone & 0.2 & 0.3 & 0.1 \\
\hline 59 & & Hexahydrofarnesyl acetone & 0.5 & 0.6 & 1.3 \\
\hline 60 & 1943 & Phytol & 1.1 & 1.4 & 0.2 \\
\hline 61 & 1960 & Palmitic acid & $\operatorname{tr}$ & 0.1 & 0.1 \\
\hline \multirow[t]{4}{*}{62} & 2500 & Pentacosane & $\operatorname{tr}$ & 0.2 & 0.6 \\
\hline & & Monoterpene & 4.1 & 3.2 & 4.4 \\
\hline & & Sesquiterpene & 56.6 & 54.7 & 49.9 \\
\hline & & Others & 39.3 & 42.1 & 45.7 \\
\hline
\end{tabular}

* The specific isomer is not identified; $\mathrm{tr}$ - traces, $<0.1 \%$; n.d.-not detected.

Our results confirm data from the literature that the essential oils of plants of the genus Stachys are poor in mono- but rich in sesquiterpene hydrocarbons [24-29]. Sesquiterpene hydrocarbons are defined as main components of the oils of six plant species of the genus Stachys (including B. officinalis and Stachys sylvatica) from Serbia [26]. Iso-caryophyllene and $\beta$-caryophyllene (22.9\%) are predominant in the essential oils of $B$. officinalis plants from 
Montenegro [24]. Sesquiterpene hydrocarbons are the most widespread class of isolated volatile compounds in both B. officinalis and S. sylvatica that grow in Bulgaria, but unlike in our study on B. bulgarica, $\gamma$-muurolene prevails [30].

\subsection{Analysis of Trace Elements}

In recent years, there has been increasing interest in certain trace elements in the environment that are considered to be a factor necessary for the proper functioning of living organisms. The contents of microelements in B. bulgarica are compiled in Table 3. The minerals are distributed in the following order: $\mathrm{Mn}>\mathrm{Sr}>\mathrm{Fe}>\mathrm{Ba}>\mathrm{Si}>\mathrm{Ti}>\mathrm{Zn}>$ $\mathrm{Cu}>\mathrm{Ba}>\mathrm{Cu}>\mathrm{Al}>\mathrm{Rb}>\mathrm{Ni}>\mathrm{Pb}>\mathrm{Mo}>\mathrm{Cr}>\mathrm{Cs}$. Except for $\mathrm{Ba}$, all other elements are found to be present in greater amounts in the leaves and inflorescences compared with the stem. The content of manganese is highest in the plant. Its main function is to participate in the biosynthesis of lipids, lignins, and carbohydrates. It is involved in photosystem II (PSII), and it plays a structural role as a cofactor in many enzymes [31]. Despite the reports of several transporter families in Mn uptake in some plants, we still have limited knowledge about many other plant species [31]. The element strontium comes second in terms of amount. Due to limited data related to the toxicity and intake of strontium, the World Health Organization has not determined ranges for the safe and adequate nutritional level of strontium. The distribution of strontium in the human body is similar to that of calcium, which means that more than $99 \%$ is deposited in bones, connective tissues, and teeth [32]. Compared with studies on other plants [15,33,34], we found high concentrations of manganese $(177.2 \mu \mathrm{g} / \mathrm{g})$ and strontium $(156.8 \mu \mathrm{g} / \mathrm{g})$ in the dry mass of the plant being examined by us, which seems to be promising for the purposes of commercial exploitation.

Table 3. ICP-MS (Inductively coupled plasma mass spectrometry) analysis of plant samples ( $\mu \mathrm{g} / \mathrm{g})$.

\begin{tabular}{|c|c|c|c|c|c|c|c|c|c|c|c|c|c|c|c|}
\hline Element & $\mathrm{Cu}$ & Zn & $\mathrm{Fe}$ & $\mathrm{Cr}$ & $\mathbf{R b}$ & $\mathrm{Si}$ & Ti & $\mathrm{Ni}$ & $\mathrm{Sr}$ & Mn & Ba & Al & Mo & Cs & $\mathrm{Pb}$ \\
\hline B. bulgarica (leaves) & $16.9 \pm 1.7$ & $28.2 \pm 0.4$ & $119.9 \pm 1.5$ & 0.29 & 8.71 & 75.6 & 71.9 & 1.02 & 123.2 & 177.2 & 62.1 & 19.4 & 0.31 & 0.16 & 0.79 \\
\hline B. bulgarica (flower) & $24.7 \pm 1.5$ & $29.05 \pm 0.3$ & $95.3 \pm 4.43$ & 0.16 & 13.95 & 67.7 & 60.2 & 0.96 & 156.8 & 67.5 & 76.2 & 12.3 & 0.16 & 0.20 & 0.90 \\
\hline B. bulgarica (stem) & $19.3 \pm 2$ & $20.3 \pm 0.5$ & $85.9 \pm 4.8$ & 0.24 & 10.42 & 63.7 & 63.6 & 0.73 & 134.3 & 104.0 & 90.3 & 16.1 & 0.17 & 0.20 & 0.91 \\
\hline
\end{tabular}

Results are presented as mean \pm SD, where $n=6$.

\section{Materials and Methods}

\subsection{Plant Material}

Aerial parts from Betonica bulgarica were collected during flowering in June-July 2019 from the Bulgarka Nature Park, the areas of Uzana $\left(42^{\circ} 45^{\prime} 02^{\prime \prime} \mathrm{N}, 25^{\circ} 14^{\prime} 18^{\prime \prime} \mathrm{E}\right)$. Plant materials were authenticated by Assoc. Prof. Plamen Stoyanov. Collected raw materials were dried at $25^{\circ} \mathrm{C}$ and powdered. Voucher specimens for Betonica bulgarica (n. 062646) were deposited at the Herbarium of the University of Agriculture, Plovdiv, Bulgaria.

Applying the classic methods of Metcalfe and Chalk [35], histology samples of fresh plant materials (leaf and stem epidermises) were prepared, after which the morphology of the identified trichomes was examined. With the help of a Magnum T microscope equipped with a photo documentation system Si5000, light microscope pictures were taken at $50 \times$ and $400 \times$ magnifications.

\subsection{Determination of Essential Oil Content}

Essential oil content was determined by means of a Likens-Nickerson apparatus. Ground plant material (5 g) was placed in a $100 \mathrm{~mL}$ round-bottom flask, and distilled water $(50 \mathrm{~mL})$ was added to it. Diethyl ether $(3 \mathrm{~mL})$ was placed in a $5 \mathrm{ml}$ round-bottom flask. Distillation lasted for 2 hours. The diethyl ether was dried with water-free $\mathrm{Na}_{2} \mathrm{SO}_{4}$ and distilled under vacuum to constant weight.

The determination of the qualitative and quantitative compositions of the essential oil obtained was carried out through chromatographic analysis (GC-MS) using a gas chromatograph Agilent 7890B with a mass selective detector Agilent 5977A; carrier gashelium, DB-5 MS column (5\% phenylmethylpolysiloxane, 30 m, 0.25 mm I.D.). 
Temperature mode: Injector and detector temperature: $260{ }^{\circ} \mathrm{C}$. Column temperature: $60{ }^{\circ} \mathrm{C}$. The temperature was held at $60^{\circ} \mathrm{C}$ for $4 \mathrm{~min}$, followed by raising it to $220^{\circ} \mathrm{C}$ at a rate of $4{ }^{\circ} \mathrm{C}$ per min. Then the temperature was increased to $300{ }^{\circ} \mathrm{C}$ at a rate of $10^{\circ} \mathrm{C}$ per min and was held at this level for $3 \mathrm{~min}$.

\subsection{Quantitative and Semiquantitative Multielement Analysis}

In the current study, an inductively coupled plasma mass spectrometry (ICP-MS) method was used for the quantitative multielement analysis of $\mathrm{Cu}, \mathrm{Zn}$, and $\mathrm{Fe}$ and the semiquantitative analysis of $\mathrm{Cr}, \mathrm{Rb}, \mathrm{Si}, \mathrm{Ti}, \mathrm{Sr}, \mathrm{Mn}, \mathrm{Ba}, \mathrm{Al}, \mathrm{Mo}, \mathrm{Cs}$, and $\mathrm{Pb}$ in nitric acid solution of B. bulgarica obtained after microwave (MW)-assisted acid mineralization. All element standards used for the preparation of the calibration standard solutions were NIST traceable.

Microwave-assisted acid mineralization was performed by a Multiwave GO microwave digestion system with closed vessels provided by Anton Paar (Graz, Austria). Multielement determination was carried out by iCAP Qc ICP-MS (Thermo Scientific, Erlangen, Germany).

\section{Conclusions}

This is the first time that the structure of trichomes that cover the leaves and stems of populations of B. bulgarica in the Bulgarka Nature Park has been studied. For the first time, peltate stacked glandular trichomes with a four-celled head of type B have been identified. These trichomes could be used as a characteristic for the taxonomic discussion of B. bulgarica and B. officinalis species. The levels of manganese $(177.2 \mu \mathrm{g} / \mathrm{g})$ and strontium $(156.8 \mu \mathrm{g} / \mathrm{g})$ are predominant in the microelement composition of the endemic B. bulgarica in the researched habitat. It is the first time that we report on the essential oil composition of $B$. bulgarica, with the predominance of sesquiterpene hydrocarbons and major components: $\beta$-caryophyllene $(17.4 \%)$, germacrene D (9.9\%), and $\beta$-bourbonene $(6.7 \%)$.

Since the growth and development of plants, as well as the synthesis and accumulation of essential oils in them, depends on the micronutrients absorbed by the roots [36], in the future, we plan to continue our research on the relationship between micronutrients and essential oils.

Author Contributions: Conceptualization, T.M. and D.G.; collection of the plants, P.S. and K.T.; methodology, D.D. and G.K.; software, D.G.; validation, T.D. and D.D.; formal analysis, P.S.; investigation, T.M.; data curation, A.B.; writing-original draft preparation, R.M.; writing-review and editing, A.B.; visualization, K.T.; supervision, A.B.; project administration, R.M. All authors have read and agreed to the published version of the manuscript.

Funding: This research received no external funding.

Acknowledgments: We would like to express our gratitude to the operational program "Science and education for smart growth" 2014-2020, grant number BG05M20P001-1.002-0005, Personalized Innovative Medicine Competence Center (PERIMED).

Conflicts of Interest: The authors declare that they have no competing interests.

\section{References}

1. Petrova, A.; Vladimirov, V.; Dimitrova, D.; Ivanova, D. Contemporary State of Biodiversity of Fern and Seed Plants in Bulgaria, Contemporary State of Biodiversity in Bulgaria; Drakon: Sofia, Bulgaria, 2005.

2. Anchev, M. General Characteristics of Bulgarian Flora and Floristic Regions in Bulgaria; Red Data Book of the Republik of Bulgaria Volume 1; Peev, D., Ed.; BAS \& MOEW: Sofia, Bulgaria, 2011.

3. Delipavlov, D.; Cheshmedzhiev, I.; Popova, M.; Terziiski, D.; Kovachev, I. Key to the Plants in Bulgaria; Delipavlov, D., Cheshmedzhiev, I., Eds.; Academic Publishing House Agricultural University: Plovdiv, Bulgaria, 2011; pp. $329-331$.

4. Jordanov, D. Flora Reipublice Popularis Bulgaricae; Bulgarian Academy of Sciences Publishing House: Sofia, Bulgaria, 1989; pp. 388-413.

5. Petkov, V. Modern Phytotherapy; State Publishing House “Medicina i Fizkultura”: Sofia, Bulgaria, 1982; pp. 387-388.

6. Staneva, D.; Panova, D.; Rajnova, L.; Assenov, I. Herbs in Every Home; State Publishing House "Medicina i Fizkultura": Sofia, Bulgaria, 1986; p. 179. 
7. Velchev, V. Atlas of Endemic Plants in Bulgaria; Bulgarian Academy of Sciences: Sofia, Bulgaria, 1992.

8. Petrova, A. Atlas of Bulgarian Endemic Plants; Gealibris: Sofia, Bulgaria, 2006.

9. Genova, E. Betonica Bulgarica; Red Data Book of the Republic of Bulgaria Volume 1; Peev, D., Ed.; BAS \& MOEW: Sofia, Bulgaria, 2011.

10. Biological Diversity Act, Republic of Bulgaria, National Assembly, Promulgated, State Gazette No 77/9.08.2002. Available online: https:/ / www.wipo.int/edocs/lexdocs/laws/en/bg/bg038en.pdf (accessed on 19 January 2021).

11. Tzanova, M.T.; Grozeva, N.H.; Gerdzhikova, M.A.; Argirova, M.D.; Pavlov, D.H.; Terzieva, S.R. Flavonoid content and antioxidant activity of Betonica bulgarica Degen et Neič. Bulg. Chem. Commun. 2018, 50, 90-97.

12. Grozeva, N.; Georgieva, M.; Vulkova, M. Flowering plants and ferns. In Biological Diversity of Sinite Kamani Nature Park Kontrast_Bogomilovo; Stoeva, M., Ed.; Trakia University: Stara Zagora, Bulgaria, 2004; pp. 9-112.

13. Grozeva, N.; Todorova, M.; Gerdzhikova, M.; Panayotova, G.; Getova, N.; Dohchev, D. New data for Bulgarian endemic Betonica bulgarica Deg. et Neič. of Sinite Kamani Natural Park Sliven. J. BioSci. Biotechnol. 2014, 2, 205-210.

14. Grozeva, N.H.; Gerdzhikova, M.A.; Pavlov, D.H.; Panayotova, G.D.; Todorova, M.H. Morphological variability of the Bulgarian endemic Betonica bulgarica Degen et Neič. (Lamiaceae) from Sinite Kamani Natural Park, Eastern Balkan Range. Acta Bot. Croat. 2016, 75, 81-88. [CrossRef]

15. Łozak, A.; Sołtyk, K.; Ostapczukc, P.; Fijałekab, Z. Determination of selected trace elements in herbs and their infusions. Sci. Total Environ. 2002, 289, 33-40. [CrossRef]

16. Kremer, D.; Stabentheiner, E.; Dunkić, V.; Dragojević Müller, I.; Vujić, L.; Kosalec, I.; Ballian, D.; Bogunić, F.; Bezić, N. Micromorphological and chemotaxonomical traits of Micromeria croatica (Pers.) Schott. Chem. Biodivers. 2012, 9, 755-768. [CrossRef]

17. Stančić, Z.; Vujević, D.; Gomaz, A.; Bogdan, S.; Vincek, D. Detection of heavy metals in common vegetables at Varaždin City Market, Croatia. Arch. Ind. Hyg. Toxicol. 2016, 67, 340-350. [CrossRef]

18. Metcalfe, C.R.; Chalk, L. Anatomy of Dicotyledons: Wood and Conclusion of the General Introduction, 2nd ed.; Clarendon Press: Oxford, UK, 1985; Volume 2, pp. 755-768.

19. Maleci Bini, L.; Giuliani, C. The glandular trichomes of the Labiatae. A Review. Acta Hortic. 2006, 723, 85-90. [CrossRef]

20. Mladenova, T.; Stoyanov, P.; Mihova-Nankova, I.; Mladenov, R.; Boyadzhiev, D.; Bivolarska, A.; Todorov, K. Comparative leaf epidermis analyses of Micromeria frivaldszkyana (Degen.) Velen. and Clinopodium vulgare L. (Lamiaceae) from Bulgarka Nature Park, Bulgaria. Ecol. Balk. 2019, 11, 133-140.

21. Giuliani, C.; Maleci Bini, L. Glandular trichomes as further differential characters between Stachys subgenus Betonica (L.) Bhattacharjee and Stachys subgenus Stachys. Plant Biosyst. 2012, 146, 1-8. [CrossRef]

22. Giuliani, C.; Pellegrino, R.; Tirillini, B.; Bini, L.M. Micromorphological and chemical characterisation of Stachys recta L. subsp. serpentini (Fiori) Arrigoni in comparison to Stachys recta L. subsp. recta (Lamiaceae). Flora-Morphol. Distrib. Funct. Ecol. Plants 2008, 203, 376-385. [CrossRef]

23. Ya'Ni, A.; Hassan, S.; Elwan, Z.; Ibrahim, H.; Eldahshan, O. Morphological and Anatomical Studies on Selected Lamiaceae Medicinal Plants in Bani Matar District, Sana'a (Yemen). Taeckholmia 2018, 38, 17-39. [CrossRef]

24. Chalchat, J.C.; Petrovic, S.D.; Maksimovic, Z.A.; Gorunovic, M.S. Essential oil of Stachys officinalis (L.) Trevis., Lamiaceae from Montenegro. J. Ess. Oil. Res. 2001, 13, 286-287. [CrossRef]

25. Radnai, E.; Dobos, A.; Vereš, K.; Töth, L.; Máthé, I.; Janisák, G.; Blunden, G. Essential oils in some Stachys species growing in hungary. Acta Hortic. 2003, 597, 137-142. [CrossRef]

26. Grujic-Jovanovic, S.; Skaltsa, H.; Marin, P.D.; Sokovic, M. Composition and antibacterial activity of the essential oil of six Stachys species from Serbia. Flavour Fragr. J. 2004, 19, 139-144. [CrossRef]

27. Tirillini, B.; Pellegrino, R.; Bini, L.M. Essential oil composition of Stachys sylvatica L. from Italy. Flavour Fragr. J. 2004, 19, 330-332. [CrossRef]

28. Vundać, V.B.; Pfeifhofer, H.W.; Brantner, A.H.; Maleš, Ž.; Plazibat, M. Essential oils of seven Stachys taxa from Croatia. Biochem. Syst. Ecol. 2006, 34, 875-881. [CrossRef]

29. Rezazadeh, S.; Pirali-Hamedani, M.; Hadjiakhondi, A.; Ajani, Y.; Yarigar-Ravesh, M.; Shafiee, A. Chemical composition of the essential oils of Stachys atherocalyx and S. sylvatica from Iran. Chem. Nat. Compd. 2009, 45, 742-744. [CrossRef]

30. Dimitrova-Dyulgerova, I.; Merdzhanov, P.; Todorov, K.; Seymenska, D.; Stoyanov, P.; Mladenov, R.; Stoyanova, A. Essential oils composition of Betonica officinalis L. and Stachys sylvatica L. (Lamiaceae) from Bulgaria. C. R. Acad. Bulg. Sci. 2015, 68, 991-998.

31. Vatansever, R.; Ozyigit, I.I.; Filiz, E. Essential and Beneficial Trace Elements in Plants, and Their Transport in Roots: A Review. Appl. Biochem. Biotechnol. 2016, 181, 464-482. [CrossRef]

32. Höllriegl, V.; München, H. Strontium in the Environment and Possible Human Health Effects. Encycl. Environ. Health 2011, 268-275. [CrossRef]

33. Er, M.; Tugay, O.; Özcan, M.M.; Ulukuş, D.; Al Juhaimi, F. Biochemical properties of some Salvia L. species. Environ. Monit. Assess. 2012, 185, 5193-5198. [CrossRef] [PubMed]

34. Zlatić, N.; Stanković, M. Effects of calcareous and serpentinite parent material on the mineral characteristics of soils and plant material of Teucrium montanum L. (Lamiaceae). Environ. Monit. Assess. 2019, 191, 564. [CrossRef] [PubMed] 
35. Metcalfe, C.R.; Chalk, L. Anatomy of the Dicotyledons: Leaves, Stem and Wood in Relation to Taxonomy with Notes on Economic Uses, 1st ed.; Clarendon Press: Oxford, UK, 1950.

36. Nazari, M.; Zarinkamar, F.; Soltani, B.M.; Niknam, V. Manganese-induced changes in glandular trichomes density and essential oils production of Mentha aquatica L. at different growth stages. J. Trace Elem. Med. Biol. 2018, 50, 57-66. [CrossRef] [PubMed] 